\title{
An Intercultural Education: Teaching Reading in a Mapuche Context
}

\author{
María Elena Mellado Hernández ${ }^{1} \&$ Adriana del Carmen Huaiquimil Hermosilla ${ }^{2}$ \\ ${ }^{1}$ Pedagogy in General Primary Education, Faculty of Education, Universidad Católica de Temuco, Temuco, Chile \\ ${ }^{2}$ Spanish Studies Program, Faculty Science of Education, Universidad San Sebastian, Puerto Montt, Chile \\ Correspondence: Adriana del Carmen Huaiquimil Hermosilla, Head of Spanish Studies Program, Universidad \\ San Sebastian, Lago Panguipulli $\mathrm{n}^{\mathrm{o}}$ 1390, Puerto Montt, Chile. Tel: 56-652-325-665. E-mail: \\ adriana.huaiquimil@uss.cl
}

Received: April 2, 2015 Accepted: May 8, 2015 Online Published: September 24, 2015

doi:10.5539/ies.v8n10p28 URL: http://dx.doi.org/10.5539/ies.v8n10p28

\begin{abstract}
In Chile, there are currently intercultural educational policies; national curricula that assume updated research development including investigational advances in reading and opportunities for improvement of teacher training. However, in La Araucania Region predominates for lagging behind in reading and it is necessary to explain this tendency beyond poverty and rural conditions of the region. In this context, the aim of this article is to understand the practices for the teaching of reading carried out by primary school teachers in rural schools in a Mapuche intercultural context, and their relationship with and between the pedagogical conceptions that underlie these teaching practices. This is a qualitative study, framed in educational investigation. Sixteen teachers were selected intentionally, 6 men and 10 women, $75 \%$ of them from Mapuche ancestry. In order to collect information, reading classes were observed using ethnographic records and the application of two Likert scale questionnaires on conceptions of teaching, learning and reading. The results show that most educators teach reading in a decontextualized manner, from the textbook of the student, with the teacher's role and focus on decoding texts. The study also shows consistency between the teachers' conceptions of learning and reading. A high percentage of these conceptions are traditional ones that lie beneath the teaching of reading. However, the study highlights that there are very little findings of reading practices that relate to the Mapuche context in which the students are situated.
\end{abstract}

Keywords: intercultural education, reading, teaching practice, teaching, teaching conceptions

\section{Introduction}

Nowadays, Chilean society is involved in an extensive debate about the need of a high quality inclusive education that can narrow the wide social gap in this country. Attention to diversity is essential from an intercultural approach that ensures all students learn out of respect for people, their differences, their knowledge and their cultural customs.

According to the 2002 census of the National Statistics Institute (INE, 2005) approximately 5\% of the Chilean population belongs to ethnic groups, most of whom belong to the Mapuche culture (87.34\%), and $33 \%$ of these reside in La Araucania Region. The region has the highest rates of poverty and unemployment in the country. According to INE poverty reaches $22.9 \%$, above the $14.4 \%$ average registered in the country. Additionally, between $80 \%$ and $100 \%$ of children attending rural schools located in the Mapuche communities of the Araucania Region are living invulnerable economic conditions (Williamson, 2004).

At the same time, the poor reading comprehension results historically achieved by the primary school students in the Araucania Region are worrying; in general they do not surpass the national average on the educational quality measurement test (SIMCE). In this sense, Fuentes (2009) in an empirical investigation carried out in this region, shows that a relationship exists between the students superficial reading comprehension, evidenced on the SIMCE reading comprehension test and Primary Intervention exam, and the vulnerability index and rural conditions of the sectors from which these students belong.

This research attempts to contribute to the comprehension of regional educational issues that affect reading development in the Mapuche intercultural context. In this context, the purpose of this article is to unveil conceptions about reading and learning that teachers of primary schools show and their relationship to the way Mapuche children of rural primary schools, in La Araucania Region, Chile are taught to read. 
The article is laid out by first presenting a brief description of intercultural education, theoretical focuses and reading conceptions. Second, a methodological section outlines the procedures of collecting and analyzing the data acquired in this study. Then the results are revealed and discussed as well as the final conclusions from this investigation.

\subsection{Intercultural Education in Intercultural Context}

The Mapuche population is an ethnic group acknowledged under the international convention $\mathrm{N}^{\circ} 169$ of the International Labour Organisation (ILO) and is recognized under educational decree 236 (October, 2008), which exists to ensure that its' program and educational services, can be developed and implemented in cooperation with this people, with the purpose of responding to ethnic needs and also encompassing their history, customs, knowledge and values that belong to the Mapuche culture. Additionally, the General Law of Education 20370 launched in 2009, contemplates interculturality as one of its main principals, establishing that the educational system should recognize and appreciate the student in his or her cultural specificity and origin, considering his or her world view, history and language.

In the same way, intercultural education has a global and inclusive vision, assumed as an orientation that intends to rethink school itself in order to guarantee students a quality education based on the principles of social justice. It's a privileged scenario for human development as it is grounded on respect and the valuing of cultural diversity, as it favors communication, learning how to coexist, and the development of intercultural competences for a social transformation that will hopefully surpass current conflicts (Gil-Jaurena, 2009; Gorski, 2010; Aguado, 2011).

Intercultural competence is a key resource when it comes to learning how to progress as a democratic society and build a common social project (Bartolomé, 2002). If we understand that cultures are not facts but rather constructions, we also, by default, accept intercultural competence from a holistic viewpoint that includes affective, cognitive, and communicative dimensions and can be defined as the capacity and resources of the people to keep a balance between reinforcing its' own identity and at the same time strengthening its' relationships with other culturally different groups.

In the process of acquiring intercultural competence, it is hoped that students and teachers progress from a monoculture level, where a foreign culture is observed and interpreted from the limits of one's own culture, to an intercultural level, where they can take on a half-way position between their own culture and the culture of another in order to be able to finally carry out the mediating function between the cultures in contact (Gudykunst, 1998).

However, Merino and Quilaqueo (2003) state that Mapuche knowledge and lifestyles are unknown by school culture. This lack of awareness effects the projection of an intercultural society, as an interethnic relationship based on the knowledge of both societies is hindered. According to Poblete (2003) Mapuche students experience culture shock once they become part of the school system, as the dominant culture seems to show very little appreciation of the ethnic group. With regards to this, Sarangapani (2003) and Essomba (2007) emphasize the importance to consider the contents and educational purposes of the indigenous communities in the school environment. That is to say, teachers must perform their usual teaching practices, a reciprocal dialogue between cultural awareness of ethnicity and what is predetermined in the national curricula. In order to make this possible, teachers must assume an intercultural approach that has as its base the mastery of pedagogical, subject or content and cultural knowledge.

Teaching with intercultural knowledge allows the teacher to articulate school contents taking into consideration the children's previous experiences, and therefore, allowing for contextualized learning scenarios that permit the students' active participation (Quintriqueo \& Torres, 2012). This teaching and intercultural leadership of teachers transforms the culture of their schools and allows developing school management in decentralized contexts (Bolivar, 2010). However, it is necessary that in addition to teachers, directors also take ownership of the policies and theoretical advances regarding interculturality in order to take into consideration these multiple identities as a clear pedagogical wealth and an educational development opportunity for ethnic minorities. Furthermore, the development of an intercultural education model demands a close working relationship between partners who have influence in the entire formative community (Leithwood \& Day, 2007; Bolívar, 2010; Day \& Gu, 2012). In other words, a joint vision of intercultural education is imperative from the educational community in dialogue with all the people who constitute the two cultures.

Therefore, from an intercultural education perspective, it is required for the teacher to value, know and respond to the cultural knowledge of the students. In this regard, Quilaqueo and Quintriqueo (2008) explain that the discourse of teachers from Mapuche background denies their culture and those teachers with a non Mapuche 
background are uninformed, product of receiving a monocultural education. As a consequence, indigenous children have been subject to an educational method that does not acknowledge their mother tongue and that is based in concepts and sociocultural representations with little meaning for them. In this sense, it is necessary for the teacher to know the objectives that intercultural education pursues and assume a commitment to both cultures, Mapuche and non Mapuche, and therefore also assumes a commitment with the fundamental principles of how to live in society (Ministerio de Educación [MINEDUC], 2011).

\subsection{Theoretical Focuses and Reading Conceptions}

The teaching of reading is a multidisciplinary pedagogical domain that has been defined from the specificity of each subject discipline. Hence, cognitive psychology has become interested in the process of recognizing words and the evaluation of the effects of different learning methods and reading improvements (Vieiro \& Gómez, 2004) in combination with other subject disciplines, such as, psycholinguistic, communication and information theory.

From this focus, lineal theory of conceived comprehension emerges as transference of information where the reader advances through different levels of analysis or language processing, from the recognition of a letter to the meaning of a word. Therefore the access to meaning of a text is a lineal process in which the reader extracts the semantic content without considering integration and semantic elaboration of the meaning (Pearson \& Stephens, 1994). This vision of the reading process is seen in the model of ascending skill translated to analytical methods, also called synthetic or syllabic, which privileges the knowledge of decodification as a needed skill previous to the development of comprehension. In this model the sociocultural context that surrounds the reading act lacks importance, as the phoneme-grapheme conversion into words and isolated phrases is exercised in a mechanical way. This way, decodification is at the center of learning, meanwhile the advances towards reading comprehension is done in a progressive way, in the extent that decodification is more fluent. Just as Cassany states (2013) in this day and age people still think that reading consists of giving voice to the letters of a text, or that it is about understanding only the meaning that appears in the text, and they avoid the interpretation from the cultural experience and previous knowledge of the readers.

On one hand, the contribution of psycholinguistic, cognitive psychology and scheme theory have given place to various studies of reading comprehension which in turn give place to an interactive conception of reading. This conception involves the active participation of the reader whom processes the information in the text from his knowledge and experience of the world, therefore, comprehension is the result of the interaction between the meaning of the text and the previous knowledge of the reader (Goodman, 1986; Smith, 1990). In this sense, Cassany (2013, p. 32) affirms that "different readers understand a text in a very different or partially different ways, given that they provide varied previous data, as their way of experiencing the world or the accumulated knowledge in their memories are different". Today there is consensus that reading is comprehending, therefore, there is no reason to separate the concept of reading from reading comprehension.

This approach is consistent with the holistic descendent model, also called integral, in which the reader constructs meaning from the text according to his previous experience and knowledge of the world, in addition to clues or evidence from the text. Under this model it is not necessary to wait for the children to fully develop their phonological awareness skills and knowledge of the written code, as it supposes the active participation of the readers, who manipulate authentic and functional texts, literary or non literary, formulate hypothesis about their content, make predictions, corroborate them and confront them at the same time they regulate their reading through metacognition (Goodman, 1986; Smith, 1990). In the same way, it is possible to associate the interactive theory of comprehension to the interactive methods that consider the learning of lexical units and their rules for its combinations, at the same time as the active construction of the meaning of texts. This active construction is developed with clear purposes and significant text for the readers (Condemarín, Galdames, \& Medina, 2004).

On the other hand, by recognizing that meaning is constructed in the mind of the reader, the transactional theory suggested by Rosenblatt (1996) highlights geographical, historical and sociocultural factors associated with the context in which the process of comprehension is produced and also factors that interfere in the construction of meaning done by the readers. This conception assumes that all reading is a transaction between the reader and the text, that is, a reciprocal relationship in which both are influenced in a dynamic and variable process where anew text is created, unique and unrepeatable. Organizing the ideas in this way, the reading process must adjust to its setting using real life situations and real texts at the moment when there is an authentic need to read (Cassany, 2013; Jolibert, 2003; I. Solé, 1992; M. Solé, 2012).

For the authors Collins and Smith (1980), Rockwell (1982) and Solé (1987) teachers' concepts regarding what it means to learn to read and the activities they take to their classrooms are interrelated. That is, teachers teach to 
read from their pre existing conceptions. According to Diaz, Martinez, Roa, and Sanhueza (2010) the teachers' methods are strongly influenced by their previous experiences as students, their professional formation and their personal beliefs on effective teaching. According to Diaz-Barriga and Hernandez (2002) the reading process has been neglected by focusing too much on teaching simple decoding skills and automation of reading, apparently teachers do not perceive learning as an authentic and socially relevant activity (Vygotski, 1979; Reid, 1993). Furthermore, Resnick (1991) states that the social context in which learning occurs is a central part of teaching, and it is not simply the context that surrounds it. These traditional reading conceptions indicate for Aguado, Gil-Jaurena, and Mata (2008) that it is necessary to center the formation of the teachers in the revision of beliefs and practices in the classroom, through a systematic reflection on teaching itself, based on theoretical orientations that may allow to transform teaching methods.

\section{Methodology}

This study is framed in an investigative educational approach to systematically build new knowledge in order to understand and improve the educational processes (Bisquerra, 2004; McMillan \& Schumacher, 2005).

\subsection{Participants}

The study focused on the Spanish and Communication subject of first and fourth grade courses of eight rural schools in a Mapuche intercultural context, which systematically present low results in the SIMCE reading test and where $90 \%$ of their students are mapuche. Four schools are administered by the municipality and four schools are subsidised, located in the districts of Temuco, Nueva Imperial, Padre Las Casas, Vilcún, Curarrehue, Freire, Tolten and Cunco, located in the province of Cautin in the Araucania Region, Chile. In each commune a public school and a subsidised school were selected by their access and relation with the Faculty of Education of Universidad Católica de Temuco. In each school two teachers were selected, therefore, the sample was intentionally chosen and not probabilistic, the subjects were 16 teachers between 30 and 50 years of age, with an average age of 39.5, 6 men and 10 women, $75 \%$ of Mapuche lineage.

\subsection{Techniques and Instruments for Data Collection}

Two data collecting techniques were used in the study. On one hand, the survey to investigate the conceptions about reading and the reading teaching process, and on the other hand, the non participant observation to identify the teaching practices. In the first data collecting technique two surveys were carried out and a two Likert-type value scale was used, the content was validated by experts (Escobar \& Cuervo, 2008). The Cronbach alpha coefficient was applied to analyse the reliability of the instruments. The questionnaire of reading conceptions obtained an alpha equivalent to .82 for a total of 33 items; whereas the questionnaire of teaching-learning conceptions presented and alpha of .87 for a total of 40 items. In addition, the class observation technique was used through non-participant ethnographic records (Anguera, Blanco-Villaseñor, \& Losada, 2001; Mauss, 2006). The observation of the teaching practices was carried out during 16 weeks, from March 2014 to July. 48 class sessions of 90 minutes equivalent to a total of 72 hours we observed.

\subsection{Data Processing and Analysis}

The quantitative data was processed using Excel, as it was considered an appropriate tool for the statistical analysis of distribution of percent frequencies. While, the qualitative information of the ethnic records were processed with the aid of the Atlas-ti software, through content analysis (Piñuel, 2002; Araneda, Parada, \& Vásquez, 2008).

\section{Results}

Firstly, the results tending to reveal the conceptions of the teaching-learning and reading process of the teachers are presented through a percent frequency analysis. Secondly, the results originated from the teaching reading class records in Mapuche context, organised in categories and subcategories are presented.

\subsection{Conceptions of Teaching-Learning and Teachers' Reading}

Table 1 presents, on one hand, the levels of agreement that the teachers of this study manifest respect to the traditional conceptions of teaching versus the current perspectives of learning construction, and on the other hand, presents the conceptions of teaching learning expressed in relation to the lineal, interactive and transactional focuses. 
Table 1. Percent frequency of learning and teaching conceptions of reading of the teachers

\begin{tabular}{llllll}
\hline Conceptions teachers have & Completely disagree & Disagree & Agree & Totally agree & Total \\
\hline & Relative percent frequency (\%) & & & \\
\hline 1. Learning-teaching process & \multicolumn{5}{c}{} \\
\hline Behaviourist conceptions of learning & 0 & 12.5 & 50 & 37.5 & 100 \\
Constructivist conceptions of learning & 6.25 & 68.75 & 6.25 & 18.75 & 100 \\
\hline 2. Teaching of reading & 6.25 & & & & \\
\hline Information transfer/decoding & 43.75 & 25 & 31.25 & 37.5 & 100 \\
Interaction between thinking and language & 31.25 & 25 & 0 & 100 \\
Transaction between the reader and the text & 50 & 37.5 & 12.5 & 0 & 100 \\
\hline
\end{tabular}

According to the analysis and interpretation of data from Table 1, teachers obtain an accumulated percent frequency of $87.5 \%$ of adhesion to behaviourist conception of learning. This traditional perspective explains why $68.75 \%$ of teachers agree or totally agree with a vision of teaching of reading as a transfer of information and decoding. Hence, the teaching that poses a traditional conception of learning also manifest to assume a lineal process of the teaching of reading. The results indicate that most teachers of the study assume the learning process as a memorising, repetitive process which is teacher centred, and where the student plays a passive role in the construction of meaning of the read text, concentrating the reading process in a mechanic exercise that is part of a restricted vision of the reading process (Pearson \& Stephens, 1994). However, 25\% of teachers agree or totally agree with the conception of teaching reading from an interactive focus that involves the active participation of the reader in the comprehension of the texts based on their knowledge and experiences (Goodman, 1986; Smith, 1990). Nevertheless, only a 12.5\% agree with the transactional conception of reading (Rosenblatt, 1996) associated to a conception of construction of learning that implies students being the protagonists in the dialogue with the text, from which meaning is constructed.

\subsection{Findings of Teaching Reading Practices}

In this section, the findings obtained from the analysis of the records about teaching reading practices are presented. A series of categories were identified from the analysis of the content, classifying the way in which reading is taught and how the reading process is produced in the observed classrooms. In first place, we show a brief description of each category and provide examples of its manifestation. The system used to identify the fragments are: R to refer to the record, EM for public school, and EPS for subsided school, P to refer to the teacher and $\mathrm{A}$ for the students.

\subsubsection{Category Teaching of Reading Practices out of Context}

This category represents approximately a $70 \%$ of the observed classes, and therefore, groups together most of the teaching of reading practices of the study. It is characterised by centring the process in decodification, teaching of reading centred in the teacher. Furthermore, the cultural context, interests, needs and previous experiences of the students are excluded at the moment of reading. In this general category we include 4 subcategories: "teaching of reading based in the decodification", "teaching of reading centred in the course book", "teaching of reading based in the teacher" and "teaching of reading that excludes Mapuche knowledge". Commented records of the classroom are presented in order to provide examples to these subcategories.

\subsubsection{Sub Category Teaching of Reading Based in the Decodification}

\section{(a) R2 EM1 P1}

Pa-Aos: "Which is the letter we have been seeing?"/speaks loudly as she looks at the class/.

Ao9-Pa: "Teacher I know, the letter is d"/rises his left hand as he observes the board/.

Pa-Ao9: "Are you sure Elizardo?"/speaks loudly as she approaches Ao9's seat/.

Ao9-Pa: "Yes, $d$ is the letter" /he speaks softly/.

Pa-Ao9: "Well done, that is the letter we have been working with. Congratulations, you've got a great memory" /she strokes his head and speaks to him softly/.

Pa-Aos: "We all are going to pronounce letter d, remember how I told you to place your tongue" /speaks loudly/. 
As seen from the record (a) the teaching of reading starts from the recognition of the letters and is centred in the capacity of decoding graphic symbols that are translated to the oral code. It is a mechanical vision of the reading process that assumes comprehension as locating explicit information in the text, to retain, and recuperate it with the purpose of retransmitting.

3.2.1.2 Subcategory Teaching of Reading Centred in the Course Book

\section{(b) R9 EM3 P5}

Pa-Aos: "Now that you are understanding much better and remembering what you are reading, we are going to do other activities from the course book related to a popular story from Tibet, "How monkeys saved the Moon", turn to page 24".

In the previously presented example (b) it is observed that the texts used in the reading practices are chosen exclusively by the teacher, and mainly taken from the student's course book provided nationwide by the Ministry of Education. Reading practices performed sequentially according to the course book, promote routine readings without much sense for the students.

\subsubsection{Subcategory Teaching of Reading Centred in the Teacher}

\section{(c) R25 EPS2 P12}

Pa-Aos: "The objective for today's class is to go deeper in the understanding of the story "The oyster that lost its pearl" that I am going to continue reading until you learn how to read". /Speaking loudly, indicates with her hand the objective written on the board/

In this record (c) it is evident that the reading process is centred in the figure of the teacher, that is to say, it is observed during the reading activities that the students are not the ones that read or interact with the text. It is the teachers belief that the students can only be active readers until they have reached complete fluency, situation that limits the development of cognitive skills implied in the inferential and appraisal understanding of the text.

\subsubsection{Subcategory of Teaching of Reading Disassociated from Mapuche Educational Knowledge}

\section{(d) R36 EPS3 P16}

Pa-Aos: "Fourth grade will work in their reading book. You are going to prepare the text we have seen, remember it was an extract of the myth Maya of Creation".

Ao6- Pa: "Teacher, mi grandma told me last Sunday the story of Xegxeg and kay-kayfilu". (Note 1)

Ao4- Pa: "I also know Mapuche stories, teacher".

Pa-Aos: "Now children, we are reading a universal story, write the questions from the course book and answer them in your notebooks".

\section{(e) R42 EPS3 P12}

Pa-Aos: "Third grade, read page 170 in the course book and make a copy of the poem "The Sun that wished to bathe" we read last class":

Ao2-Pa: "Teacher we bathe with the Moon for wetripantu". (Note 2)

Aa5-Ao2: "We also bathe in the estuary and wait at dawn for the sun to rise".

Pa-Ao2; Ao5:"Do not talk much and finish your copy, break is coming shortly"

In the records (d) and (e) it is demonstrated that the teachers exclude the educational knowledge belonging to Mapuche people when the students express their vision of the cosmos and origin of their culture. Therefore, students are not considered as readers having knowledge built from their own cultural models. Hence, the intercultural dialogue between school knowledge and the Mapuche knowledge becomes difficult.

\subsubsection{Category Teaching of Reading Practices with Meaning for the Students}

This category represents approximately a $20 \%$ of all of the observed classes, and therefore, groups a little percentage of the teaching of reading practices found in the study. It has been decided to include in this study, as an example, some subcategories that could result useful for those students that do not visualise the teaching of reading from a cultural context, interests, needs and previous experiences of the students. In this category 4 subcategories are included: "teaching centred in the meaning from text building" "teaching of reading authentic and meaningful" "teaching of reading that incorporates the mapuche sociocultural context" and "teaching of reading that articulated the school and mapuche knowledge. 


\subsubsection{Subcategory Teaching Centred in the Meaning from Text Building}

\section{(a) R5 EM2 P3}

Pa-Aos: "Children, look at this page, what is happening?"

Some. Aos-Pa: "They are signs!"

Pa-Aos: "What these signs tell us?"

Ao4-Pa: "Teacher, I have seen them in town"

Pa-Ao4: "Very well Andres. They are seen in town. What is their use?"

Ao4-Pa: "So cars are aware of us, and the school"

Pa-Aos: "Hey, children! There is a very common warning sign here in the country. Which one?" /Children are wondering/

Pa-Aos: "It is connected with our animals".

Ao8-Pa: "The one where you see a cow".

Pa-Ao8: "Good job, Rodrigo! A yellow sign having a cow in the centre".

Aa2-Pa: "It means there are cows there".

Pa-Aa2: "Excellent Viviana, what information does the sign give us?"

Aa10-Pa: "Teacher, they are for the drivers to drive carefully".

In the previous example (a) the teacher uses different teaching techniques to help students build meaning from the text they read. These reading practices promote dialogues, debates and drama representations giving the children the chance to exchange ideas about what they read, socialized, experience and learn with their classmates and teacher, allowing to transform the texts.

3.2.2.2 Subcategory Teaching of Reading Authentic and Meaningful

\section{(b) R8 EM4 P7}

Pa-Aos: "Pay attention children, we are going to continue with our reading and writing project. Today we have to dramatise the poem about the protection of nature we were reading".

Some Aas-Pa: "Teacher, I want to be the machi!; I want to be the machi too!; Let's Maka be the machi!".

Some Aos-Pa: "Teacher, I want to be the Mapuche boy!; I want to be the wigka, teacher! (Note 3)

Pa-Aos: "Students, remember to show the relation with nature and your territory".

Ao4-Pa: "Teacher, can we make the Mapuche boy to ask permission to enter the forest and then he gets lost, the trees speak to him, and that he cries and ask them to protect him.

Pa-Ao4: "Yes, excellent idea, but and the wigka boy, what does he do?".

Some Aos-Pa: "Teacher, so then he does not ask permission to enter; he throws garbage and burns down the trees

Pa-Aos: "The wigka children will also protect nature, the same as we will do".

Ao3-Pa: "Then, I am the wigka boy that protects the forest".

In the record (b) it can be observed that the students have an active and creative role as readers as they interact with texts about daily stories. The reading activity is meaningful from the sociocultural environment of the students and at the same time it is authentic, as it considers the needs and interests of the students and with specific purposes. Furthermore, the teacher recognises, values and integrates the different interpretations that the students build from the texts they read.

3.2.2.3 Subcategory Teaching of Reading Linked to the Mapuche Sociocultural Context

\section{(c) R20 EPS1 P10}

Pa-Aos: "Ok, students!, we will develop the class with the reading of a epew". (Note 4)

Pa-Aos: "Which epew wants to read?"

Ao5-Pa: "Teacher, why don't we read a piam instead?".

Aa3-Pa: "Yes...Xegxeg and kay-kayfilu!". 
Pa -Aos: "What if I read the epew "The fox and the partridge" to you (soft voice)?

Aos-Pa: "Yeeeeesssss!".

Pa-Aos: "Listen, please all be seated in a circle, listening". /The teacher reads the epew while the children carefully pay attention/

Pa-Aos: "What do you think about the epew?, Did you like it?".

Aos-Pa: "Yeeees, another one please".

Pa-Aos: "What called your attention?".

Ao4-Pa: "I liked it when the mouth of the guru (fox) unstitched because it was evil".

Pa-Aos: "Well and what did today's epew teach you?".

Aa6-Pa: "We do not have to lie or cheat".

Pa-Aos:" OK students, we have read an oral story from our culture that teach us values, knowing how to live with others and with the nature".

In this record (c) it can be observed that the teacher constantly incorporates in the reading situations proper oral dialogues of the Mapuche Culture. It can be inferred that the teacher is familiar and values the mapuche language and education.

\subsubsection{Subcategory Teaching Reading Putting Together School Knowledge with Mapuche Cultural Knowledge}

\section{(d) R30 EPS4 P15}

Po-Aos: "Students, remember that during the Spanish class we are developing our class project, do you remember the project's name?".

Some Aos-Pa: "Yes teacher! Learning intercultural recipes".

Po-Aos: "You had to interview you moms about Mapuche meals as homework. We have already searched in Internet Chinese, Italian, German recipes...."

Ao12-Po: "I wrote it, my mom dictated to me, can I read my recipe, teacher?".

Po-Aos: "Attention please!, we will listen to Sebastian's recipe". /The student reads his multrun recipe aloud/ (Note 5)

Po-Aos:" "Thank you Sebastian!, Then, what are the recipe's characteristics?".

Some Aos-Pa: "The ingredients!; the preparation too!; the ingredients are mixed!; it is similar to the fruit salad recipe we prepared in class!".

Po-Aos: "Excellent children! You have learned very well the recipe's structure, put your things in order and go for a break. Do not forget to bring your recipes next class to do an intercultural recipe book".

In this record (d) it is observed that some reading practices use intercultural educational strategies from socialisation of Mapuche and non-Mapuche values, beliefs and customs among students and teachers that promote a construction between school knowledge, family and community environment. In these reading practices the students participate with their own knowledge that is valued and authorised as educational contents by the teacher, linking the curricular content referred to instructive non-literary texts as the recipe case. Therefore the teacher carries out reading practices that promote the interaction between school knowledge and cultural knowledge of the students.

\section{Discussion}

The research shows that the teaching reading practices in schools located in a Mapuche intercultural context are not coherent with the current education orientation about reading, learning and intercultural education. In other words, there is inconsistency between the theoretical advances and the pedagogy practices of teachers, that demonstrate a pedagogical management in the classroom based on traditional approaches. The teacher practices account for resisting reference frameworks that need to be modified as they affect the quality of the teaching reading process and the possibility of an intercultural pedagogy that could allow a dialogue between the school knowledge and the Mapuche culture knowledge and therefore, overcome the restrictive vision of the intercultural education.

As a consequence, it can be concluded that the development of the reading process is done mainly from a lineal theoretical construction, centred in decoding and that believes that understanding is related with memorisation 
and reproduction of information. To that respect Cassany (2013, p. 21) states that "many people still think that reading consists of making graphical symbols oral, giving the silent letter its voice". In this sense, it is worrying that despite the deep knowledge that this investigation offers about learning of reading, the teachers have nor changed their convictions of reading understood as decoding, and understanding assumed as the explicit reproduction of information from a text. The previous statements provide an explanation of why classroom practices have not suffered substantial changes and why the reading activities have not been centred in the students' active construction of meanings. However, it must be remarked that the findings of some reading practices allow readers to interact and give meaning to the text from their previous knowledge. These results confirm Jolibert $(2003$, p. 27) statement that "reading is to directly attribute a sense to the written language [...], without considering neither the decoding nor the oral process".

On the other hand, it can be confirmed that a traditional pedagogical approach of the process underlies to these lineal reading practices, which also assume unidirectional methods centred in the teacher and in teaching. In this sense, it can be stated that the beliefs of teachers explain the teaching practices of teachers, that is to say, there is a relation between the pedagogical and reading conceptions teachers have, and that the type of teaching reading process they perform in the classroom (Collins \& Smith, 1980; Rockwell, 1982; I. Sole, 1987).

In this context, teaching reading seems out of context from the environment where the reading process is carried out. Thus, teachers tend to ignore that knowledge is a product of social and cultural interaction, in other words, most of them do not see learning as a socially situated activity and improved in functional, meaningful and authentic contexts (Vigotsky, 1979; Reid, 1993).

In consequence, it is imperative for the reading process to consider previous experiences and knowledge students have with the purpose of giving functionality and meaning to learning and obtain contextualised knowledge construction from cultural references. In this sense, Quintriqueo and Torres (2012) state that children socialise in the interior of their families and learn a series of contents that provides them with cultural knowledge and allows them to understand the sociocultural reality. Then, it is necessary and appropriate for teachers to assume that learning happens because of the social group culture he/she belongs to, which establishes and models the type of specific learning and educational experiences. So then, the social context in which the cognitive activity is done is an integral part of the pedagogical action, not simply a context surrounding it (Resnick, 1991). Considering this logic, it is been assured that reading must be a cultural practice situated in the context, and done from itself, this is to say, a process related to the dialogue between the reader, text and context (Rosenblatt, 1996; Jolibert, 2003; Cassany, 2013).

On the other hand, the educational knowledge of the Mapuche was generally excluded by some of the teachers in the study and therefore, provided evidence of the depreciation of the Mapuche knowledge, as teaching is limited only to the school knowledge of the country curriculum. In this way, the reading practices reproduce the standardised education model from the dominant culture. In consequence, Poblete (2003) gives evidence of the low appraisal of the Mapuche culture provoked by the constant transmission of stereotyped contents about the Mapuche origins and costumes that confirm a stigmatised identity accepted as fair by the country's society. According to this context, the need of an intercultural pedagogy that appraise the learned knowledge in the family and social context as educational contents is presented and could put them together with the school knowledge as conditions to develop the intercultural education in the classrooms (Sarangapani, 2003; Essomba, 2007; Quilaqueo \& Quintriqueo, 2008).

Finally, it is necessary to modify the traditional conceptions of reading, learning and intercultural process that are in the base of the pedagogical practices, since they act as filters of the current theoretical advances and prevent the transformation and improvement of the teacher's performance. To facilitate reconstruction of these conceptions it is essential to assume the permanent reflexion as a teachers' training strategy that promotes the revision of teachers' beliefs and practices (Aguado et al., 2008).

We believe that building an intercultural focus and developing this competency should be supported by the strategy of permanent pedagogical reflection that is defined as action-reflection-action, this is to say, a permanent dialogue between theory and practice that allows reflexive thinking and questioning of our beliefs and educational practices. Formation in methodology, techniques and reviewing concepts alone isn't enough to think that with this alone conceptual diagrams and teachers' attitudes when facing cultural diversity will be changed, since intercultural competence requires the developing of certain affective and emotional aspects, among these we can highlight a special attitude, sensibility and empathy towards other cultures. We also consider that this strategy should be approached from a critical paradigm (Hartfold \& MacRuairc, 2008; Zeichner \& Listón, 1999), since this perspective emphasizes the reflection upon social-political implications involved in the act of teaching 
and with regards to education as a way of developing abilities and individual strategies for living in a multicultural society (Aguado et al., 2008). As a result, the responsibility of opening spaces for pedagogical reflexion oriented to professionalize teachers lays in the pedagogical management at institutional and classroom levels, with the purpose of transforming the school centres in real learning communities.

\section{Conclusion}

The result analysis shows that most of the teachers assume traditional conceptions of learning teaching of reading and not only a minority of them manifest most agreement with the current conceptions of the learning and reading processes. In other terms, the direct relations that exist between the conceptions of learning and reading of the teachers and their teaching performance in the schools exist at the moment of teaching to read. As a consequence, it is posible to refer to these representations no only as a way to see the reality, but they act as filters that determine the teaching practices.

The analysis of the teaching of reading practices of the teachers participating in this study evidenced a predominance in the focus of traditional teaching and from the lineal reading model. In general, the teachers devoted most of their time to performing reading activities based in decodification, where reading is defined as the process of decoding the written code, and comprehension is understood as the memorisation and reproduction of information. The role of the students during the reading process was almost always passive therefore, and centred in the teacher that performed the readings and commanded the students to review explicit information of the read texts. Even though there is predominance in this traditional focus, a smaller group of teachers that developed teaching practices based on learning and the student was found, they stimulated the development of comprehension by inferring and valuing as a way to transcend from mere content repetition.

With relation to the focus of intercultural education in teaching of reading in Mapuche context, the results indicate that most of the observed teachers teach to read from a monocultural perspective that mainly considers knowledge of the dominant occidental culture. This situation is manifested in the omission of the $\mathrm{s}$ in the construction of learning. Such exclusion is originated, within other factors, from the lack of knowledge and little value of the contextual value of the mapuche culture. However, what is most concerning is that a $75 \%$ of the teachers participating in the study were of mapuche ancestry, for which we can state that indigenous background of teachers does not guantee intercultural teaching. This scenario of out of context reading practices could explain the low reading results in the region of La Araucania, as it is a reading comprehension process of the children and move their knowledge, and experiences to construct the meaning of texts.

In this sense, it is essential to generate systematised and effective reflection spaces in the schools that promote between teachers the questioning of their traditional references in teaching and in reading. In other words, future investigations should provide guidelines of teaching can be modified to change the conceptions that underline their way of teaching of reading, as this study has showed that they are essential in the design of the activities in the classroom. From this pedagogical reflexion it should be possible that teachers reach a concept of reading defined as a complex process that integrates the emotional nature of the children and the geographic, historical and sociocultural factors of the context in which they live. In general terms, it is crucial to grant cultural diversity the value it deserves and should be considered by the teachers when designing significant teaching of reading situations. Therefore, the process of comprehension and construction of meaning that the readers carryout would be favoured and would also promote interaction between school knowledge and cultural knowledge of the students.

\section{References}

Aguado, T. (2011). El enfoque intercultural en la búsqueda de buenas prácticas escolares. Revista Latinoamericana de Educación Inclusiva, 5(2), 23-42.

Aguado, T., Gil-Jaurena, I., \& Mata, P. (2008). El enfoque intercultural en la formación del profesorado. Dilemas y propuestas, Revista Complutense de Educación, 19(2), 275-292.

Anguera, M. T., Blanco-Villaseñor, A., \& Losada, J. L. (2001). Diseños observacionales, cuestión clave en el proceso de la Metodología Observacional. Metodología de las Ciencias del Comportamiento, 3(2), 135-160.

Araneda, A., Parada, M., \& Vásquez, A. (2008). Investigación Cualitativa en Educación y Pedagogía. Concepción: Universidad Católica de la Santísima Concepción.

Bartolomé, M. (2002). El reto de las migraciones en sociedades multiculturales desde la perspectiva de la educación. En C. Morano (Ed.), Fe y Cultura: encuentros, desencuentros y retos actuales. Salamanca: Universidad Pontificia de Salamanca. 
Bisquerra, R. (2004). Metodología de la investigación educativa. Madrid: Editorial La Muralla.

Bolívar, A. (2010). Cómo un liderazgo pedagógico y distribuido mejora los logros académicos? Revisión de la investigación y propuesta. Magis, Revista Internacional deInvestigación en Educación, 3(5), 79-106. Retrieved from http://magisinvestigacioneducacion.javeriana.edu.co/

Cassany, D. (2013). Tras las líneas. Sobre la lectura contemporánea. Barcelona: Editorial Anagrama.

Collins, A., \& Smith, E. (1980). Teaching the process of Reading comprehension. Technical Report $\mathrm{n}^{\circ} 182$. Urbana, Illinois. Center for the Study of reading.

Condemarín, M., Galdames, V., \& Medina, A. (2004). Taller de Lenguaje. Santiago: Santillana.

Day, C., \& Gu, Q. (2012). Profesores: vidas nuevas, verdades antiguas. Madrid: Narcea.

Decreto Ley $\mathrm{N}^{\circ} 236$. Promulga el convenio $\mathrm{N}^{\circ} 169$ sobre pueblos indígenas y tribales en países independientes de la Organización Internacional del Trabajo. Diario Oficial de la República de Chile, Santiago. Octubre, 2008.

Díaz, C., Martínez, P., Roa, I., \& Sanhueza, M. (2010). Los docentes en la sociedad actual: sus creencias y cogniciones pedagógicas respecto al proceso didáctico. Polis, Revista de la Universidad Bolivariana, 9(25), 421-436.

Díaz-Barriga, F., \& Hernández, G. (2002). Estrategias docentes para un aprendizaje significativo. México: McGraw-Hill.

Escobar, J., \& Cuervo, A. (2008). Validez de contenido y juicio de expertos: una aproximación a su utilización. Revista Avances en Medición, 6, 27-36.

Essomba, A. (2007). Liderar escuelas interculturales e inclusivas. Equipos directivos y profesorado ante la diversidad cultural y la inmigración. Barcelona: GRAÓ.

Fuentes, L. (2009). Diagnóstico de comprensión lectora en educación básica en Villarrica y Loncoche, Chile. Perfiles educativos, 31(125), 23-37.

Gil-Jaurena, I. (2009). Diversidad cultural en educación obligatoria. ¿Qué sucede en las escuelas? En M. Fernández, \& W. Mullauer-Seichter (coords.), La integración escolar a debate (pp. 143-169). Madrid: Pearson/Prentice Hall.

Goodman, K. (1986). El lenguaje integral. Buenos Aires: Aique.

Gorski, P. (2010). The scholarship informing the practice: Multicultural teacher education philosophy and practice in the United States. International Journal of Multicultural Education, 12(2), 1-22.

Gudykunst, W. (1998). Applying anxiety/uncertainty management (AUM) theory to intercultural adaptation training. International Journal of Intercultural Relations, 22(2), 227-250. http://dx.doi.org/10.1016/s0147-1767(98)00005-4

Harford, J., \& G. MacRuairc. (2008). Engaging student teachers in meaningful reflective practice. Teachers and teachers education, 24(7), 1884-1892. http://dx.doi.org/10.1016/j.tate.2008.02.010

Instituto Nacional de Estadística. (2005). Estadisticas Sociales de los pueblos indígenas en Chile-Censo 2002. Santiago: Ministerio de Planificación Nacional.

Jolibert, J. (2003). Formar niños lectores de textos. Santiago: LOM

Leithwood, K., \& Day, C. (2007). What we learned: A broad view. In C. Day, \& K. Leithwood (Eds.), Successful Principal Leadership in Times of Change: An International Perspective (pp.189-203). Toronto: Springer.

Ley General de Educación ( $N^{\circ}$ 20.370). Diario Oficial de la República de Chile, Santiago. Septiembre, 2009.

Mauss, M. (2006). Manual de etnografia. Buenos Aires: Fondo de Cultura Económica.

McMillan, J., \& Schumacher, S. (2005). Investigación educativa. Madrid: Pearson Educación.

Merino, M., \& Quilaqueo, D. (2003). "Ethnic prejudice against the Mapuche in Chilean society as a reflection of the racist ideology of the Spanish Conquistadors". American Indian Culture and Research Journal, 27(4), 105-116.

Ministerio de Educación. (2011). PEIB-ORIGENES Estudio sobre la implementación de la Educación Intercultural Bilingüe. Santiago, Ministerio de Educación. 
Pascual, G., \& Goikoetxea, E. (2005). Prueba de Comprensión Lectora e Intervención para Primaria CLIP v5. Manual de Aplicación. Deusto: Universidad de Deusto.

Pearson, D., \& Stephens, D. (1994). Learning about literacy: A 30-year journey. In H. Singer, \& B. Rudell (Eds.), Theoretical models and processes of reading (pp. 22-103). Newark: IRA.

Piñuel, J. (2002). Epistemología, metodología y técnicas del análisis de contenido. Revista Estudios de Sociolinguística, 3(1), 1-42.

Poblete, R. (2003). Políticas y prácticas en educación intercultural: una aproximación comparativa. Barcelona: Universidad Autónoma de Barcelona.

Quilaqueo, D., \& Quintriqueo, S. (2008). Formación docente en educación intercultural para contexto mapuche en Chile. Cuadernos interculturales, 6(10), 91-110.

Quintriqueo, S., \& Torres, H. (2012). Distancia entre el conocimiento mapuche y el conocimiento escolar en contexto mapuche. Revista Electrónica de Investigación Educativa, 14(1), 16-33. Retrieved from http://redie.uabc.mx/vol14no1/contenido-quintriqueotorres.html

Reid, D. (1993). Another vision of "visions and revisions". Remedial and Special Education, 14(4), 14-16. http://dx.doi.org/10.1177/074193259301400403

Resnick, L. (1991). Shared Cognition: Thinking as Social Practice. In L. Resnick, J. Levine, \& S. Teasley (Eds.), Perspectives on Socially Shared Cognition (pp. 1-20), Washington, D.C.: American Psychological Association.

Rockwell, E. (1982). Los usos escolares de la lengua escrita. En E. Ferreiro, \& M. Gómez (Comp.), Nuevas perspectivas sobre los procesos de lectura y escritura (pp. 296-320). México, D. F.: Siglo XXI.

Rosenblatt, L. (1996). La teoría transaccional de la lectura y la escritura. En Textos en contexto. Los procesos de lectura y escritura (pp. 13-70). Buenos Aires: Proyecto Editorial Lectura y Vida.

Sarangapani, P. (2003). Constructing School Knowledge: An Ethnography of Learning in an Indian Village. New Delhi: Sage.

Smith, F. (1990). Para darle sentido a la lectura. Madrid: Editorial Antonio Machado.

Solé, I. (1987). L'ensenyament de la comprensión lectora. Barcelona: CEAC.

Solé, I. (1992). Estrategias de lectura. Barcelona: Editorial GRAÓ.

Solé, M. (2012). Guías de lectura contextualizadas. Revista Educere, 16(55), 293-298.

Vieiro, P., \& Gómez, I. (2004). Psicología de la Lectura. Madrid: Pearson Educación.

Vygotski, L. S. (1979). El desarrollo de los procesos psicológicos superiores. Barcelona: Critica/Grijalbo.

Williamson, G. (2004). Estudios sobre la Educación para la Población Rural en Chile. En FAO/UNESCO/CIDE/REDUC/COOPERAZIONE ITALIANA. Educación para la población rural en Brasil, Chile, Colombia, Honduras, México, Paraguay y Perú, 93-163. Roma: Unesco.

Zeichner, K., \& Listón, D. (1987). Enseñar a reflexionar a los futuros docentes. En Pérez, Barquín y Angulo, Desarrollo profesional docente: Política, investigación y práctica (pp. 506-532). Madrid: AKAL.

\section{Notes}

Note 1. Story about the Mapuche movement that explains the origin of their culture and society.

Note 2. Ritual of the Mapuche culture about restoring balance in Nature.

Note 3. No person Mapuche.

Note 4. Oral Mapuche tale with valoric content.

Note 5. A food made from ground wheat similar to bread.

\section{Copyrights}

Copyright for this article is retained by the author(s), with first publication rights granted to the journal.

This is an open-access article distributed under the terms and conditions of the Creative Commons Attribution license (http://creativecommons.org/licenses/by/3.0/). 